\title{
An ethnobotanical study of plants used by forest fringe communities of Lwali village (Pauri Garhwal, Uttarakhand)
}

\author{
Nidhi Bisht, Praveen K. Verma, Ranjana Negi and Anup Chandra
}

Botany Division, Forest Research Institute, Dehradun, India

Article history

Received: 05 December 2017

Accepted: 02 February 2018

Published: 01 April 2018

(C) Bisht et al (2018)

Editor

Afroz Alam

Publisher

Horizon e-Publishing Group

Correspondence

Praveen K. Verma

$\triangle$ pkverma bryo@yahoo.co.in

\begin{abstract}
The paper provides information on traditional knowledge of plants used by fringe forest communities of village Lwali (District Pauri Garhwal). The paper deals with 35 plant species belonging to 34 genera of 29 families, that find mention in the local folklore. The plants have been provided with botanical names, vernacular names, parts used and ethnobotanical uses.
\end{abstract}

Keywords
Ethnobotany; Fringe communities; Lwali village; Pauri Garhwal; Uttarakhand

\section{Citation}

Bisht N, Verma PK, Negi R, Chandra A. An ethnobotanical study of plants used by forest fringe communities of Lwali village (Pauri Garhwal, Uttarakhand). Plant Science Today 2018;5(2):39-43. https://dx.doi.org/10.14719/pst.2018.5.2.365

\section{Introduction}

Ethnobotany is a traditional branch of science which deals with the utility of various plants species as food, fodder, fruit, fiber, medicine and other forest based products. World health organization (WHO) estimated that $80 \%$ of the population of developing countries used traditional medicine in the form of various plant parts (1).

Uttarakhand, a part of western Himalaya has a geographical coverage of over 5.37 Lakh $\mathrm{km}^{2}$ with a diverse assemblage of natural ecosystems ranging from Cold arid ecosystems of Nilang valley to moist lowland forest ecosystems of Tarai region. The state has a vast floristic wealth which consists of a range of plants with medicinal, fodder, fiber, timber values etc. The Indian Himalayan region is the abode of about 18,440 plant species (2) many of which have medicinal properties. Uttarakhand alone contains $c a .4700$ species, 1503 genera and
213 families of flowering plants, 487 species of ferns and 18 species of gymnosperms (3).

Several forest fringe communities inhabiting in Uttarakhand particularly in the rural areas are dependent on the plant derived medicines which are prepared from locally available plants. In the rest of India as well, traditional medicinal knowledge has been used in curing ailments. Several reports on the Ethnobotany of Uttarakhand have been published in the last two decades (4-33).

Garhwal Himalayan region of Uttarakhand has been reservoir of enormous natural wealth and traditional medicinal knowledge. Several fringe forest villages situated in district Pauri Garhwal, harbor rich traditional ethnobotanical knowledge which is yet to be explored and documented. Therefore the present study was conducted to document various plants and their traditional uses so as to preserve the knowledge for future generations. 
During this study, information of 35 plant species was collected from fringe forest village of Lwali, which has been presented here.

\section{Materials and Methods}

Study area: The village Lwali (district Pauri Garhwal) is situated at $30^{\circ} 7^{\prime} 13^{\prime \prime} \mathrm{N}$ and $78^{\circ} 44^{\prime} 6^{\prime \prime} \mathrm{E}$, at an elevation of $1351 \mathrm{~m}$. The fringe forest of the village is mainly covered by conifer and oak forests. The prevalent species are Pinus roxburghii Sarg., Quercus leucotrichophora A.Camus, Myrica esculenta Buch.-Ham. ex D. Don, Rhododendron arboreum Sm. and Cornus capitata Wall.

Methodology: The present investigation is a result of extensive and intensive field surveys, conducted at Lwali village in different seasons during the year 2017. All through the surveys, plant specimens were collected and authenticated at DD Herbarium, Forest Research Institute, Dehradun. Medico-ethnobotanical uses have also been appended wherever applicable. The ethnobotanical information related to collected specimens were gathered through direct observation, guided field walk, survey and semistructured personal interviews with key informants and knowledgeable society members based on a checklist of questions prepared before hand in English and simultaneously translated into Garhwali. Out of the total population of 105 people inhabiting this small hamlet of 25 houses, thirty informants (12 males and 18 females) aged 14 to 83 were interviewed. Random sampling techniques were employed to choose traditional herbalists and common informants. Old women of the village were more knowledgeable in herbal healing and consequently most of the practitioners were women. The information was further confirmed by cross examination of informants of different age groups. Informant's demographic features including sex, age, occupation and time spent by the informant in the study area were also taken into account. The major part of the interviews focused on the local names of plants used, their habits, plant part/s used, remedy preparation methods and materials used during preparation.

\section{Results and Discussion}

A total of 35 plant species belonging to 34 genera and 29 families were recorded including 17 herbs, 8 trees, 7 shrubs, and 3 climbers (Table 1). Most of the species recorded had medicinal properties and were used in traditional healing practices. Many of the species also had other uses and were indispensable in the day to day lives of the people. Thus most of the plant species had multiple uses. Grewia optiva J.R.Drumm. ex Burret locally called Bhimal have many uses; leaves are used as fodder, young stems are used to wash hair by women, fiber is extracted from its wood which is also used as fuel. Ficus palmata Forssk. (Jangali anjir) and Ficus auriculata Lour. (Timla) fruits are relished by villagers; in fact popular folk songs of the village allude to these trees. The herbs and shrubs are easily available and are seen growing in the forest fringe as well as in the fields. Elderly women of the village had greater traditional knowledge than the younger generation.

The use of traditional healing methods was much higher among the upper age group when compared to the lower age group. One of the problems faced during interviews the informants knew the use of a particular plant and its properties but was not aware of the vernacular name and hence referred to the plant simply as vanaspati. However the use of certain medicinal plants is kept secret and disclosing the information is believed to reduce the effectiveness. As a result of modernization efforts, hospitals and clinics have come up in the village. The younger generation favour the fast-acting allopathic medicines that give quick relief. They are either totally unaware of the traditional uses of the plants or have limited information on the most frequently used ones. Thus there is a gradual erosion of traditional knowledge.

\section{Conclusion}

The study concludes that forest fringe communities of Lwali village utilized 35 plant species in different forms mainly as medicines for curing different ailments. During the study it has been found that that the decreasing dependence on forests has resulted in the rapid loss of traditional knowledge. Due to urban migration there has been a demographical change, with a predominantly aging population in the villages. Shifting trends in healing methods were also observed. Due to the increasing availability of modern allopathic medicines, the traditional healing methods have unfortunately taken a back seat.

\section{Competing interests}

The authors have declared that no competing interests exist.

\section{Authors contributions}

PKV conceived the idea and helped in manuscript writing. Field visit, collection and identification of specimen was done by NB. RN and AC contributed in specimens identifications and Manuscript corrections.

\section{Acknowledgements}

The authors thank the Director, Forest Research Institute Dehradun for providing the necessary facilities. Authors also thank the anonymous reviewers for their valuable suggestions on previous version of the manuscript. 
Table 1: Enumeration of plants used by Forest Fringe Communities of Lwali village, Pauri Garhwal

\begin{tabular}{|c|c|c|c|c|c|c|}
\hline $\begin{array}{l}\text { S. } \\
\text { No. }\end{array}$ & $\begin{array}{l}\text { Vernacular } \\
\text { name }\end{array}$ & Botanical name of plant & Family & Habit & $\begin{array}{l}\text { Plant part/s } \\
\text { used }\end{array}$ & Uses \\
\hline 1 & Kirmoli & Thalictrum clavatum D.C. & Ranunculaceae & Herb & Roots & $\begin{array}{l}\text { Cured worms in to kill } \\
\text { intestine worms of the kid }\end{array}$ \\
\hline 2 & Timru & Zanthoxylum armatum D.C. & Rutaceae & Shrub & Stem & Mouth cleaner \\
\hline 3 & Kingoda & Berberis asiatica Roxb. ex D.C. & Berberidaceaeae & Shrub & Roots & Diabetes \\
\hline 4 & Bhaang & Cannabis sativa Linn. & Cannabaceae & Shrub & $\begin{array}{l}\text { Roots, } \\
\text { Leaves, Fiber }\end{array}$ & To get rid of drowsiness \\
\hline 5 & Kadhwi & Roylea cinerea D. Don. & Lamiaceae & Shrub & Leaves & Used in heal the boil \\
\hline 6 & Neelkanthi & Elephantopus scaber Linn. & Asteraceae & Herb & Leaves & $\begin{array}{l}\text { Cure for intestinal worms } \\
\text { specially for kids }\end{array}$ \\
\hline 7 & Almoru & Rumex hastatus D. Don. & Polygonaceae & Herb & Leaves & $\begin{array}{l}\text { Use for healing on } \\
\text { wounds and cuts }\end{array}$ \\
\hline 8 & Genthi & Dioscorea bulbifera Linn. & Dioscoreaceae & Climber & Fruits & Diabetes \\
\hline 9 & Gindaru & Stephania glabra (Roxb.) Miers & Menispermaceae & Climber & Roots & $\begin{array}{l}\text { Stomachache, } \\
\text { constipation }\end{array}$ \\
\hline 10 & Hinsar & Rubus ellipticus Sm. & Rosaceae & Shrub & Whole plant & Diarrhea \\
\hline 11 & Toon & Toona ciliata M. Roem. & Meliaceae & Tree & Bark & $\begin{array}{l}\text { Healing wounds as well } \\
\text { as timber }\end{array}$ \\
\hline 12 & Samoya & Valeriana jatamansi Jones & Valerianaceae & Herb & Whole Plant & $\begin{array}{l}\text { Leaves kept in clothes, } \\
\text { paste applied on body on } \\
\text { wedding }\end{array}$ \\
\hline 13 & Kachoor & $\begin{array}{l}\text { Curcuma zeodaria (Christm.) } \\
\text { Roscoe }\end{array}$ & Zingiberaceae & Herb & Rhizomes & $\begin{array}{l}\text { Paste applied on body on } \\
\text { wedding ceremony }\end{array}$ \\
\hline 14 & Akhrot & Juglans regia Linn. & Juglandaceae & Tree & Fruits & Cure for ringworm \\
\hline 15 & Lichkur & Sigesbeckia orientalis Linn. & Asteraceae & Herb & Leaves & $\begin{array}{l}\text { For heal wounds \& blood } \\
\text { clots }\end{array}$ \\
\hline 16 & Bedu & Ficus palmata Forssk. & Malvaceae & Tree & Fruits & As fruit \\
\hline 17 & Timla & Ficus auricalata Lour. & Moraceae & Tree & Fruits & Quickly heal clot \\
\hline 18 & Bhimal & $\begin{array}{l}\text { Grewia optiva J.R. Drumm. ex } \\
\text { Burret }\end{array}$ & Moraceae & Tree & $\begin{array}{l}\text { Leaves, } \\
\text { Branches }\end{array}$ & $\begin{array}{l}\text { Hair dandruff and anti } \\
\text { fungal as well as fine } \\
\text { fiber }\end{array}$ \\
\hline 19 & Binda & Colebrookea oppositifolia Sm. & Lamiaceae & Shrub & Leaves & Wounds healing \\
\hline 20 & Chirchita & Achyranthes aspera Linn. & Amaranthaceae & Herb & Seeds & Fever \\
\hline 21 & Papkakani & Celastrus paniculatus Willd. & Celastraceae & Climber & Seeds & $\begin{array}{l}\text { Seed oil applied to skin } \\
\text { itching }\end{array}$ \\
\hline 22 & Mehal & $\begin{array}{l}\text { Pyrus pashia Buch.-Ham. ex } \\
\text { D.Don }\end{array}$ & Rosaceae & Tree & Fruits & Digestive disorder \\
\hline 23 & Lingoda & $\begin{array}{l}\text { Diplazium esculentum (Retz.) } \\
\text { Sw. }\end{array}$ & Athyriaceae & Herb & Leaves & As vegetable \\
\hline 24 & Bishkhap & Boerhavia diffusa Linn. & Nyctaginaceae & Herb & $\begin{array}{l}\text { Leaves and } \\
\text { stem }\end{array}$ & $\begin{array}{l}\text { Piles, urinary troubles, } \\
\text { dropsy condition, } \\
\text { Inflammatory renal } \\
\text { diseases }\end{array}$ \\
\hline 25 & Genti & Boehmeria rugulosa Wedd. & Urticaceae & Tree & Bark & Blood coagulation \\
\hline 26 & Gokharu & Tribulus terrestris Linn. & Zygophyllaceae & Herb & Seeds & $\begin{array}{l}\text { Gout and urinary } \\
\text { disorder }\end{array}$ \\
\hline 27 & $\begin{array}{l}\text { Pathar } \\
\text { chatta }\end{array}$ & Bergenia ciliata (Haw.) Sternb. & Saxifragaceae & Herb & $\begin{array}{l}\text { Leaves as } \\
\text { well as whole } \\
\text { plant }\end{array}$ & $\begin{array}{l}\text { Dissolving kidney stones } \\
\text { and urinary releases }\end{array}$ \\
\hline 28 & Kharna & $\begin{array}{l}\text { Eupatorium adenophorum } \\
\text { Hort.Berol. ex Kunth }\end{array}$ & Asteraceae & Herb & Leaves & Wounds \\
\hline 29 & Bhilmori & Oxalis corniculata Linn. & Oxalidaceae & Herb & Leaves & Cough and bronchitis \\
\hline 30 & Dubla & Cynodon dactylon (L.) Pers. & Poaceae & Herb & Roots & Fever \\
\hline 31 & Kansura & Commelina benghalensis Linn. & Commelinaceae & Herb & Leaves & Swelling in body \\
\hline 32 & Kuthhi & Dicliptera bupleuroides Nees & Acanthaceae & Herb & $\begin{array}{l}\text { Seeds and } \\
\text { leaves }\end{array}$ & $\begin{array}{l}\text { Used for dysentery in } \\
\text { children }\end{array}$ \\
\hline 33 & Kandali & Urtica dioica Linn. & Urticaceae & Herb & Whole plants & $\begin{array}{l}\text { Stem used as fiber; fresh } \\
\text { leaves as vegetable }\end{array}$ \\
\hline 34 & Saunla & Rhus parviflora Roxb. & Anacardiaceae & Shrub & Branches & Teeth cleaner \\
\hline 35 & Reetha & Sapindus mukorossi Gaertn. & Sapindaceae & Tree & Fruits & Hair shampoo \\
\hline
\end{tabular}




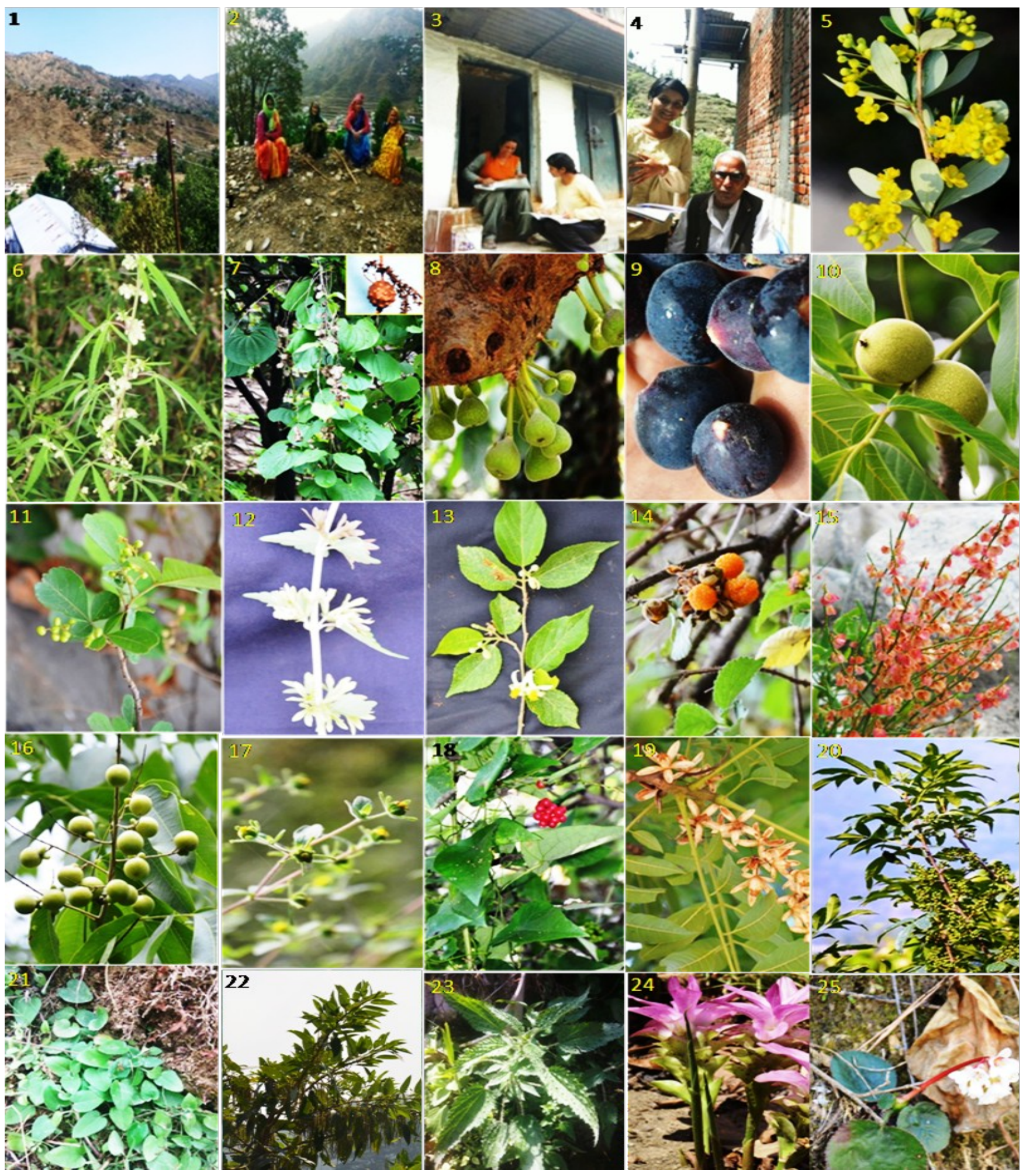

Fig. 1-25. 1-4. Interaction with inhabitant, 5. Berberis asiatica Roxb. ex D.C., 6. Cannabis sativa Linn., 7. Dioscorea bulbifera Linn., 8. Ficus auricalata Lour., 9. Ficus palmata Forssk., 10. Juglans regia Linn., 11. Rhus parviflora Roxb., 12. Roylea cinerea D. Don., 13. Grewia optiva J.R. Drumm. ex Burret, 14. Rubus ellipticus Sm., 15. Rumex hastatus D. Don., 16. Sapindus mukorossi Gaertn., 17. Sigesbeckia orientalis Linn., 18. Stephania glabra (Roxb.) Miers, 19. Toona ciliata M. Roem., 20. Zanthoxylum armatum D.C, 21. Valeriana jatamansi Jones, 22. Boehmeria rugulosa Wedd., 23. Urtica dioica Linn., 24. Curcuma zeodaria (Christm.) Roscoe, 25. Bergenia ciliata (Haw.) Sternb.

\section{References}

1. Akerele, O. Nature's medicinal bounty: don't throw it away. World Health Forum. 1993;14390-395.

2. Singh D K, Hajra P K. Floristic diversity. In: Gujral GS, Sharma V eds. Biodiversity Status in the Himalaya. New Delhi: British Council, 1996. Pp. 2338.
3. Uniyal B P, Sharma J R, Choudhery, U, Singh, D K. Flowering Plants of Uttarakhand (A Check List). Bishen Singh Mahendra Pal Singh Dehradun, 2007. Pp. 404.

4. Bisht M K, Bhatt K C, Gaur R D. Folk Medicines of Arakot Valley in district Uttarkashi In: Indian Medicinal Plant (ed. Kaushik, P.) 1985. Pp. 157-165. 
5. Joshi D N, Rawat G S. Need for conservation and propagation of alpine and sub alpine medicinal plants of northwest Himalaya. Indian Forester 1997; 123(9): 8111-814.

6. Samant S S, Dhar U, Palni L M S. Medicinal plants of Himalaya, diversity, distribution and potential values, Gyanodaya Prakashan, Nainital, 1998.

7. Nautiyal S, Rao K S, Maikhuri, R K, Semwal R L, Saxena K G. Traditional knowledge related to medicinal and aromatic plants in tribal societies in a part of Himalaya. Journal of Medicinal and Aromatic Plant Sciences, 2001; 22(4A) \& 23(1A): 528-541.

8. Bhadula S K, Singh A, Lata H, Kuniyal C P, Purohit A N. Distribution pattern, population diversity and propagation of some high altitude medicinal herbs from Garhwal Himalaya: Problem and Prospects for Conservation. In: High Altitudes of the Himalaya II (Biodiversity, Ecology, and Environment). (eds. Pangtey, Y.P.S.). Gyanodaya Prakashan,Nainital, 2002. Pp. 389-413.

9. Dhar U, Rawal R S, Upreti J. Setting priorities for conservation of medicinal plants - A case study in the Indian Himalaya. 2002. Ppp. 57-65.

10. Joshi B D. A brief review on the flora of medicinal importance and prospects of developing a sustainable net work of small scale pharmaceutical industries in Uttaranchal. Himalayan Journal of Environment and Zoology 2002; 16(2): 233.

11. Tiwari L, Pande P. Ethnoveterinary medicines in Indian perspective: Reference to Uttarakhand, Himalaya. Indian Journal of Traditional Knowledge, 2009; 9(3): 611-617.

12. Dangwal L R, Sharma A, Rana C S. Ethno- medicinal plants of the Garhwal Himalaya used to cure various diseases. A case study. New York Science Journal, 2010; 3(12): 28-31.

13. Gangwar R S, Joshi B D. Some medicinal flora in the riparian zone of river Ganga at Saptrishi, Haridwar, Uttaranchal. Himalayan Journal of Environment and Zoology, 2006; 20(2): 237-241.

14. Gangwar K, Deepali K, Gangwar R S. Ethnomedicinal Plant Diversity in Kumaun Himalaya of Uttarakhand, India. Nature and Science, 2010; 8(5): 66-78.

15. Nazir A P, Negi, A K, Todaria N P. Traditional uses of medicinal plants of Pauri Garhwal, Uttarakhand. Nature and Science, 2010; 8(6): 57-61.

16. Pant $\mathrm{H}$ M. Study on traditional knowledge of Himalayan medicinal plants of Rath region of Uttarakhand. Res. J. Agric. Sci.2010; 1(3): 277-279.

17. Semwal D, Saradhi P P, Kala C, Sajwan B. Medicinal plants used by local Vaidyas in Ukhimath block, Uttarakhand. Indian Journal of Traditional Knowledge, 2010; 9(3): 480-485.

18. Tiwari J K, Ballabha R, Tiwari P. Ethnopaediatrics in Garhwal Himalaya, Uttarakhand, India (Psychomedicine and Medicine). NewYork Science Journal, 2010, 3 (4): 123-126.

19. Phondani P C. Worth of Traditional Herbal System of Medicine for Curing Ailments Prevalent Across the Mountain Region of Uttarakhand, India Journal of Applied Pharmaceutical Science, 2011; 1(9): 81-86.

20. Singh G, Rawat GC. Ethnomedicinal survey of Kedarnath wildlife sanctuary in Western Himalaya, India. Indian J. Fundam. Appl. Life Sci. 2011; 1: 35-46.
21. Bisht V K, Rana C S, Negi J S, Bhandari A K, Purohit V, Kuniyal C P, Sundriyal R C. Lamiaceous ethnomedico-botanicals in Uttarakhand Himalaya, India. Journal of Medicinal Plants Research, 2012; 6(26): 4281-4291. https://doi.org/10.5897/JMPR12.110

22. Ballabha R, Singh D, Tiwari J K, Tiwari P. Diversity and availability status of ethno-medicinal plants in the Lobha range of Kedarnath Forest Division (KFD), Garhwal Himalaya. Global. J. Med. Plants Indigenous Med.2013; 2(4): 198- 212.

23. Chandra K, Nautiyal B P, Nautiyal M C. Herbal-based Traditional Medicinal Knowledge of Local Inhabitants in Rudraprayag District of Uttarakhand, India. Ethnobotany Research \& Applications, 2013; 11: 299-313.

24. Sharma J, Gairola S, Gaur R D, Painuli R M, Siddiqi T O. Ethnomedicinal plants used for treating epilepsy by indigenous communities of sub Himalayan region of Uttarakhand, India. J. Ethnopharmacol. 2013; 28(1): 353-370. https://doi.org/10.1016/j.jep.2013.08.052

25. Singh V R. Indigenous uses of medicinal and edible plants of Nanda Devi biosphere reserve- A review based on previous studies. Global J. Res. Med. Plants Indigenous Med. 2014; 3(2): 57-66.

26. Singh P, Attri B L. Survey on traditional uses of medicinal plants of Bageshwar valley (Kumaun Himalaya) of Uttarakhand, India, International Journal of Conservation Science, 2014; 5(2): 223234.

27. Singh H, Husain T, Agnihotri P, Pande P, Khatoon S. An ethnobotanical study of medicinal plants used in sacred groves of Kumaon Himalaya, Uttarakhand, India. Journal of Ethnopharmacology, 2014; 98-108. https://doi.org/10.1016/j.jep.2014.03.026

28. Kala C P. Herbal treatment for snakebites in Uttarakhand state of India. Indian Journal of Traditional Knowledge, 2015; 56-61.

29. Tewari R M Chaubey S, Kotecha M, Kour G D, Singh R.. Ethnobotanical Survey of Chandi Devi Hills of Haridwar, Unique Journal of Ayurvedic and Herbal Medicines, 2015; 3(4): 31-41.

30. Padalia K. Gewai saag: A folk medicine used by the tribal people of Central Himalayan region. Indian Journal of Traditional Knowledge, 2015; 1(1): 144146.

31. Priyanka, Baunthiyal M. An ethno-botanical study of medicinal plants of Ghurdauri region, Uttarakhand. India Journal of Medicinal Plants Studies, 2016; 4 (5): 200-205.

32. Bohra N, Tewari L M, Tewari A. Ethnobotany of wild edible plants traditionally used by the local people in the Ramnagar region from Nainital District, Uttarakhand, India. Biolife, 2017; 5(1):1219.

33. Khajuria A K., Bisht N S. Diversity with ethnomedicinal notes on Orchids: A case study of Nagdev forest range, Pauri Garhwal, Uttarakhand, India. Journal of Medicinal Plant Studies, 2017; 5(1):171-174. 